\title{
The Influences of Climate Change on the Runoff of Gharehsoo River Watershed
}

\author{
Kazem Javan, Farzin Nasiri Saleh, Hamid Taheri Shahraiyni \\ Faculty of Civil and Environmental Engineering, Tarbiat Modares University, Tehran, Iran \\ Email: kazem.javan.tmu@gmail.com
}

Received October 1, 2013; revised November 2, 2013; accepted November 29, 2013

Copyright (C) 2013 Kazem Javan et al. This is an open access article distributed under the Creative Commons Attribution License, which permits unrestricted use, distribution, and reproduction in any medium, provided the original work is properly cited.

\begin{abstract}
The purpose of this study is to survey the impact of climate change on the runoff of Gharehsoo River in northwest of Iran. In this research the outputs of monthly precipitation and temperature data of PRECIS model, which is a regional climate model with $50 \times 50 \mathrm{~km}$ resolution on the basis of B2 scenario, have been utilized for base (1961-1990) and future (2071-2100) periods. The output results of PRECIS model show that the average temperature of watershed increased up to $2^{\circ} \mathrm{C}-5^{\circ} \mathrm{C}$. In addition, future precipitation is more than the base precipitation on January, February, March, September and December. The observed data of 1996-2002 used for calibration of HSPF model and the data of 2003-2004 were used for HSPF validation. The present monthly patterns for precipitation and temperature were estimated using the geostatistical techniques and the future monthly patterns were retrieved by the combination of future monthly PRECIS data and monthly patterns of precipitation and temperature. Then, the base and future precipitation and temperature patterns were introduced to validate HSPF model for the simulation of monthly runoff in the base and future periods. The results show that in the future, the discharge of Gharehsoo River watershed decreases in all of the months. In addition, the peak discharge in the future period happens one month earlier, in April, because of increase of temperature and earlier beginning of snow melting season. Finally the sensitivity analysis was performed on the monthly runoff. The results showed that monthly discharge increases $0.3 \%-35.6 \%$ and decreases $0.3 \%-32.6 \%$ due to $20 \%$ increase and decrease of precipitation, respectively. In addition, $1{ }^{\circ} \mathrm{C}$ and $2{ }^{\circ} \mathrm{C}$ increase of temperature leads to $0 \%-$ $8 \%$ and $0.1 \%$ - $15 \%$ decrease of average monthly discharge, respectively.
\end{abstract}

Keywords: Climate Change; HSPF Model; Regional Climate Model; Gharehsoo River

\section{Introduction}

Climate change can influence the ecosystems, environment and water resources. One of the most important impacts of climate change is the changes of regional and local available water. Different studies have been performed on the impact of climate change on the water resources [1-5]. Recently, some studies have been performed on the impacts of climate change on water resources in Asia. Chen et al. [6] analyzed the climate change in the Danjiangkou reservoir that is a source of water in China. The results for period 2021-2050 showed that runoff and precipitation of Danjiangkou reservoir will increase in all of the seasons. Sensitivity analysis in their study revealed that $1{ }^{\circ} \mathrm{C}$ and $2{ }^{\circ} \mathrm{C}$ increases in temperature reduce the mean annual runoff about $3.5 \%$ and $7 \%$, respectively and $10 \%$ and $20 \%$ decrease/increase of mean monthly precipitation decreases/increases the mean annual runoff about $15 \%$ and $30 \%$, respectively. Akhtar et al. [7] showed that estimates of runoff changes in three river basins in the Hindukush-Karakorum-Himalaya region are related to the climate change. In this study, PRECIS Regional Climate Model was utilized for the simulation of future climate. The results showed that the temperature and precipitation will increase at the end of $21^{\text {st }}$ century. Vicuna et al. [8] studied on the impacts of climate change scenarios in the north-central Chile in the first half of the $21^{\text {st }}$ century. Their results showed an increase in temperature of about $3^{\circ} \mathrm{C}-4^{\circ} \mathrm{C}$ and a reduction in precipitation of $10 \%-30 \%$ during the first half of $21^{\text {st }}$ century. Zarghami et al. [9] used General Circulation Models (GCM) to predict the climate change. They used the three scenarios (A1B, A2 and B1) with the horizons 2020, 2055 and 2090. Their study revealed that average annual temperature will increase $2.3^{\circ} \mathrm{C}$ and annual precipitation will decrease about $30 \%$ in the middle of 
this century.

In this study, the impacts of climate change on the Gharehsoo River runoff were investigated. A new method was developed for reasonable prediction of spatial patterns of precipitation and temperature. This method uses the results of a Regional Climate Model (PRECIS model) coupled with the appropriate spatial modeling techniques. HSPF model was used to simulate the future runoff of Gharehsoo River. Different studies demonstrated the ability of HSPF for runoff simulation [10-14].

\section{The Study Area}

The present study was conducted for the watershed of Ardebil province in North-western Iran, which lies between latitude $37^{\circ}$ to $38^{\circ} \mathrm{N}$ and longitude $47^{\circ}$ to $48^{\circ} \mathrm{E}$ (Figure 1). The geographical information and the mean observed climate data for the main synoptic stations of the province for the baseline years between 1996 and 2004 are presented in Table 1. The mean annual precipitation in this watershed (stations are presented in Table 1) is very little in comparison with world average of $800 \mathrm{~mm}$. In recent years, the water shortage in Ardebil city (the capital of the province) for the reason that used in excess of water resource in agricultural province and industry consumptions has become change into a serious problem for this province.

There are very strict conflicts on using its recharge sources and new water transfers are limited. The water providing to the cities is now more vulnerable, and the Ardebil Regional Water Company needs to notice the future trend lines of the climate and their impacts on the water resources. This data aids them to understand the extents of the uncertainties and the real threats they will face in future years. The purpose of this research is therefore to predict the climate change and its impacts on the water resources in this regional.

\section{Methodology}

This algorithm of this study is presented in Figure 2. It has two important steps: First, it prepares the future me-

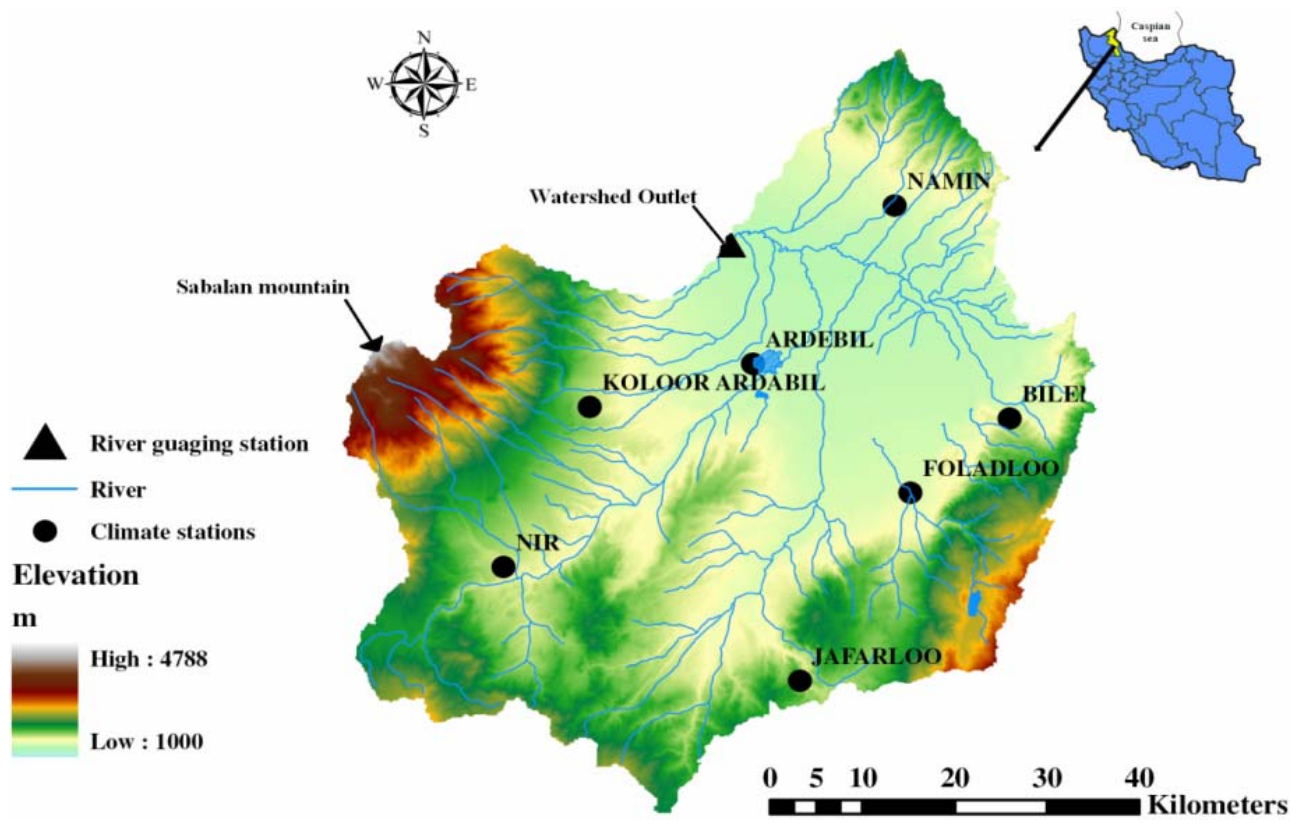

Figure 1. Gharehsoo River watershed and its location in Iran with its topography, drainage network and meteorological stations.

Table 1. The positions and the averages of the temperature and precipitation of seven synoptic stations.

\begin{tabular}{|c|c|c|c|c|c|c|c|}
\hline & & & & Stations & & & \\
\hline & Ardebil & Bile & Foladloo & Jafarloo & Namin & Nir & Koloor Ardebil \\
\hline Latitude $\left({ }^{\circ} \mathrm{E}\right)$ & 38.25 & 38.02 & 38.12 & 37.92 & 38.42 & 38.03 & 38.20 \\
\hline Longitude $\left({ }^{\circ} \mathrm{N}\right)$ & 48.28 & 48.60 & 48.48 & 48.35 & 48.45 & 47.98 & 48.08 \\
\hline Elavation (m) & 1332 & 1680 & 1490 & 1680 & 1500 & 1450 & 1581 \\
\hline Available data (years) & $1951-2007$ & $1975-2007$ & 1994-2007 & $1969-2007$ & $1960-2007$ & $1960-2007$ & $1975-2007$ \\
\hline Mean temperature $\left({ }^{\circ} \mathrm{C}\right)$ & 10.3 & 8.4 & 6.3 & 7.6 & 8.3 & 7.4 & 8.4 \\
\hline
\end{tabular}


teorological data for region under a scenario, and second, it assesses the impacts of climate change on Gharehsoo River watershed by using the HSPF model.

\subsection{Climate Change Data by PRECIS and Preparation}

Despite the important increase in the resolution of General Circulation Models (GCMs), they cannot yet predict meteorological outputs for small scales. Different dynamic and statistical models have developed to downscale the GCM outputs. The PRECIS (Providing Regional Climates for Impacts Studies) model is a RCM (Regional Climate Model) that it was developed by the Hadley center on the basis of the atmospheric of HadCM3 [15] to generate high resolation climate change scenarios as described in Jones et al. 2004 [16]. The PRECIS simulated region with a horizontal resolution of $50 \times 50 \mathrm{~km}$. The base climate (1961-1990) and future climate SRES B2 scenario (2071-2100), have been selected. Comparison between observed data and PRECIS Model simulated data of the base period (1961-1990) demonstrated that there is an appropriate similarity between these two data

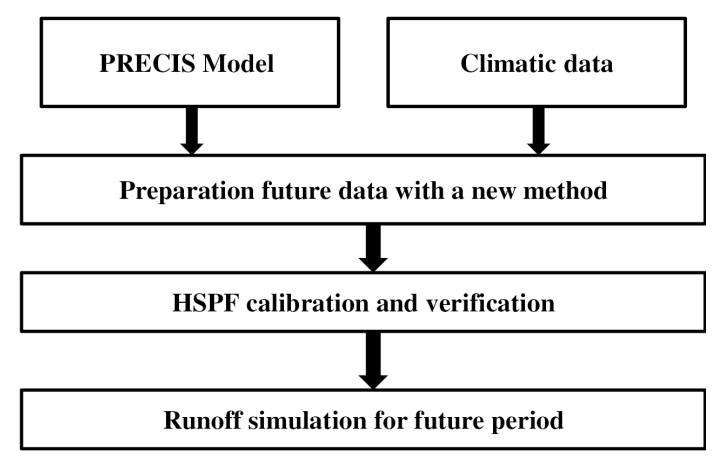

Figure 2. The algorithm of study. series; so that, the base data series of PRECIS model could be used for the runoff simulation using HSPF during the base period. Statistical analysis of precipitation and temperature data series (observed and output data of PRECIS model) shows that these two time series have approximately the same mean and standard deviation. In the study, we have applied a new method for preparing future data that the algorithm of calculation is as below. In the study, we have applied a new method for preparing future data that the algorithm of calculation is as below.

First, it's necessary to have a series of precipitation and temperature unit patterns in producing of these patterns in monthly periods in future. This series of maps are generated using the precipitation and temperature patterns of present data. For this work, we use of interpolation methods for preparation these patterns. Utilizing interpolation methods to estimate hydrological parameters can increase the accuracy of rainfall-runoff calculations [17]. These methods are including of Inverse Distance Weighting (IDW), Global Polynomial, Local Polynomial, Radial Basis Functions (RBF), Ordinary Kriging and Simple Kriging. The cross validation technique is utilized for identification of the best interpolation technique for each month. Then, precipitation and temperature unit patterns by the algorithm of calculation are as follows. Figure 3 shows use of the new approach for preparation precipitation unit pattern in future.

Using of algorithm Figure 3, the appropriate present unit patterns (maps) are determined for each month and in the other word, 12 monthly present unit patterns (maps) are generated. Then, the future patterns are calculated using the following formula:

$$
\begin{aligned}
f m p_{i} & =p m p_{i} \times\left(f h_{i} / p h_{i}\right) \\
f m t_{i} & =p m t_{i} \times\left(f t_{i} / p t_{i}\right)
\end{aligned}
$$

Supply and preparation monthly precipitation data of observed data

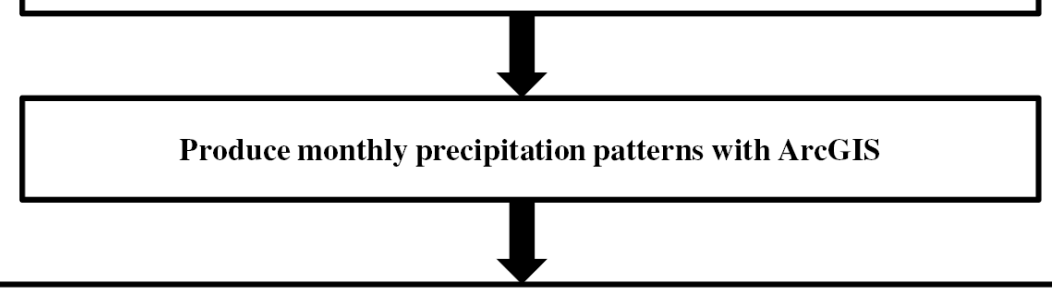

Total volume of monthly precipitation pattern / Watershed area = Mean elevation of presipitation in each month

Monthly precipitation pattern / Mean elevation of precipitation in each month= Monthly precipitation unit pattern

Figure 3. Algorithm of the new approach for preparation precipitation unit pattern in future. 
Where, $f m p_{i}$ and $f m t_{i}$ are future patterns of precipitation $(\mathrm{mm})$ and temperature $\left({ }^{\circ} \mathrm{C}\right)$ in month $i$-th $(i=1 \cdots 12)$, respectively. ${ } m p_{i}$ and $p m t_{i}$ are present unit patterns of precipitation $(\mathrm{mm})$ and temperature $\left({ }^{\circ} \mathrm{C}\right)$ in month $i$-th, respectively and are calculated using interpolation techniques as explained above. $f h_{i}$ and $f t_{i}$ are future mean precipitation $(\mathrm{mm})$ and temperature $\left({ }^{\circ} \mathrm{C}\right)$, respectively and are calculated using the PRECIS model. $p h_{i}$ and $p t_{i}$ are present mean precipitation $(\mathrm{mm})$ and temperature $\left({ }^{\circ} \mathrm{C}\right.$ ), and are calculated by averaging of $p m p_{i}$ and $p m t_{i}$ patterns, respectively.

\subsection{HSPF Hydrological Model}

In this study, we use of Hydrological Simulation Program FORTRAN (HSPF) for simulation outlet discharge of Gharehsoo River watershed. HSPF is a set of computer codes, developed by the US Environmental Protection Agency. It is based on the Stanford Watershed Model IV [18]. HSPF has been generated by the combination of Stanford Watershed Model IV with Agricultural Runoff Management Model (ARM) [19], Non-point Source Runoff Model (NPS) [20], and Hydrological Simulation Program (HSP) [21-23]. This model can simulate the hydrologic processes on permeable and impermeable land surfaces and streams [24]. It has been widely used in Asian and other parts of the world in the climate change studies [13,14,25].

HSPF is a semi distributed deterministic, continuous and physically based model. The PERLND, IMPLND, and RCHRES modules are three main modules of HSPF which help to simulate permeable land segments, impermeable land segments, and free-flow reaches, respectively. Detailed information about these modules can be found in the literatures [20,24,26,27]. HSPF model uses a Storage Routing technique to route water in each reach. Infiltration in permeable land is calculated based on Richard's equation [24]. Actual evapotranspiration (ET) is calculated by Penman or Jensen formulas. Table 2 shows key HSPF parameters. These parameters should be calibrated during the calibration process. LZSN is the most important parameter in infiltration capacity which is called in HSPF with the INFILT parameter. AGWRC is depended on topography, climate, soil properties and land use. UZSN is influenced of LZSN [11]. Other parameters that they have not presented in Table 2 are estimated using the BASINS software based on topographic, soil properties and land use data. Then the estimated paprameters are introduced to HSPF. The data from 1996 to 2002 were utilized for HSPF model calibration and the data from 2003-2004 were used as validation dataset.

\section{Results and Discussion}

\subsection{Calibration and Validation of HSPF Model}

7-year daily average discharge data of Gharehsoo River of 1996-2002 are used for calibration of HSPF model in the simulation of daily discharge in the hydrometric outlet station of Samian. Two years (2003-2004) are used for the model validation. Table 3 shows the values of calibrated parameters in this study. For example, LZSN in Table $\mathbf{3}$ is an average value $38.1 \mathrm{~mm} / \mathrm{h}$ that has been estimated according to the Linsley equation [29]. Linsley equation for the LZSN estimation is $\mathrm{LZSN}=100+0.25$ $\times$ (Yearly mean precipitation). For estimation of the other parameters, BASINS Technical Note 6 [28] has been utilized.

Figures 4 and 5 show the observed and simulated hydrographs for calibration and validation periods, respectively. These figures present good agreement between observed and simulated daily runoff in the calibration and validation periods. The correlation coefficients for calibration and validation periods are 0.814 and 0.806 , respectively. It implies that HSPF simulation is acceptable. Moreover, Nash-Sutcliff coefficient (model efficiency) is 0.87 in calibration period and 0.76 in validation period. Nash-Sutcliffe efficiency coefficient value less than 0.5 are considered as unacceptable, while values greater than 0.6 are considered as good and greater than 0.8 are considered excellent results. Therefore, HSPF has been presented good daily runoff simulation. Results show that HSPF simulation of watershed discharge is acceptable in calibration period and can be used in this research.

Table 2. The parameters of HSPF model in simulation process [28].

\begin{tabular}{|c|c|c|c|c|}
\hline \multirow{2}{*}{ Parameter } & \multirow{2}{*}{ Definition } & \multirow{2}{*}{ Units } & \multicolumn{2}{|c|}{ Possible range } \\
\hline & & & MIN & MAX \\
\hline INFILT & Index of infiltration capacity & $\mathrm{mm} / \mathrm{h}$ & 0.25 & 12.7 \\
\hline AGWRC & Base groundwater recession & dimensionless & 0.85 & 0.999 \\
\hline LZSN & Lower zone nominal soil moisture storage & $\mathrm{mm}$ & 50.8 & 381 \\
\hline UZSN & Upper zone nominal soil moisture storage & $\mathrm{mm}$ & 1.27 & 50.4 \\
\hline DEEPFR & Fraction of groundwater inflow to deep recharge & dimensionless & 0 & 0.5 \\
\hline INTFW & Interflow inflow parameter & dimensionless & 1 & 10 \\
\hline IRC & Interflow recession parameter & dimensionless & 0.3 & 0.85 \\
\hline BASETP & Fraction of remaining ET from base flow & dimensionless & 0 & 0.2 \\
\hline LZETP & Lower zone ET parameter & dimensionless & 0.1 & 0.9 \\
\hline
\end{tabular}




\subsection{Future Changes of Temperature and Precipitation}

Figure 6 shows the average of 30-years monthly temperature in Ardabil station for the base (solid line) and future (dash line) periods. As it is shown, this scenario forecasts that temperature will increase in Ardabil station in all of the seasons. Temperature increases $2^{\circ} \mathrm{C}-4^{\circ} \mathrm{C}$ in winter, $2^{\circ} \mathrm{C}-5^{\circ} \mathrm{C}$ in spring, $3^{\circ} \mathrm{C}-5^{\circ} \mathrm{C}$ in summer and $2^{\circ} \mathrm{C}$ $4^{\circ} \mathrm{C}$ in autumn. Maximum temperature will happen in July and the Minimum temperature will take place in January. Figure 7 shows the average of 30-year monthly precipitation in Ardabil station for the base and future

Table 3. Values of parameters, used in simulation.

\begin{tabular}{cc}
\hline Parameter & Value \\
\hline INFILT & $0.35 \mathrm{~mm} / \mathrm{h}$ \\
AGWRC & 0.977 \\
LZSN & $38.1 \mathrm{~mm}$ \\
UZSN & $22.86 \mathrm{~mm}$ \\
DEEPFR & 0.2 \\
INTFW & 2 \\
IRC & 0.9 \\
BASETP & 0.1 \\
LZETP & 0.7 \\
\hline
\end{tabular}

periods. Future precipitation is more than the base precipitation on January, February, March, September and December.

PRECIS model forecasts that maximum precipitation happens on February and the minimum on July. It is concluded that climate change impacts on climate variables such as temperature and precipitation of Gharehsoo river watershed in the future; although according to Figures 6 and 7, the impact of climate change on temperature would be more than precipitation. Comparison between observed data and PRECIS Model simulated data of the base period (1961-1990) demonstrated that there is an appropriate similarity between these two data series; so that, the base data series of PRECIS model could be used for the runoff simulation using HSPF during the base period. Statistical analysis of precipitation and temperature data series (observed and output data of PRECIS model) shows that these two time series have approximately the same mean and standard deviation.

In order to prepare base monthly precipitation and temperature patterns, different geostatistical methods are compared to each other using cross validation technique. Tables 4 and 5, show RMSE (Root Mean Square Error) values of the six interpolation methods for precipitation and temperature data, respectively. Results show that RBF and IDW methods can be utilized for preparation of

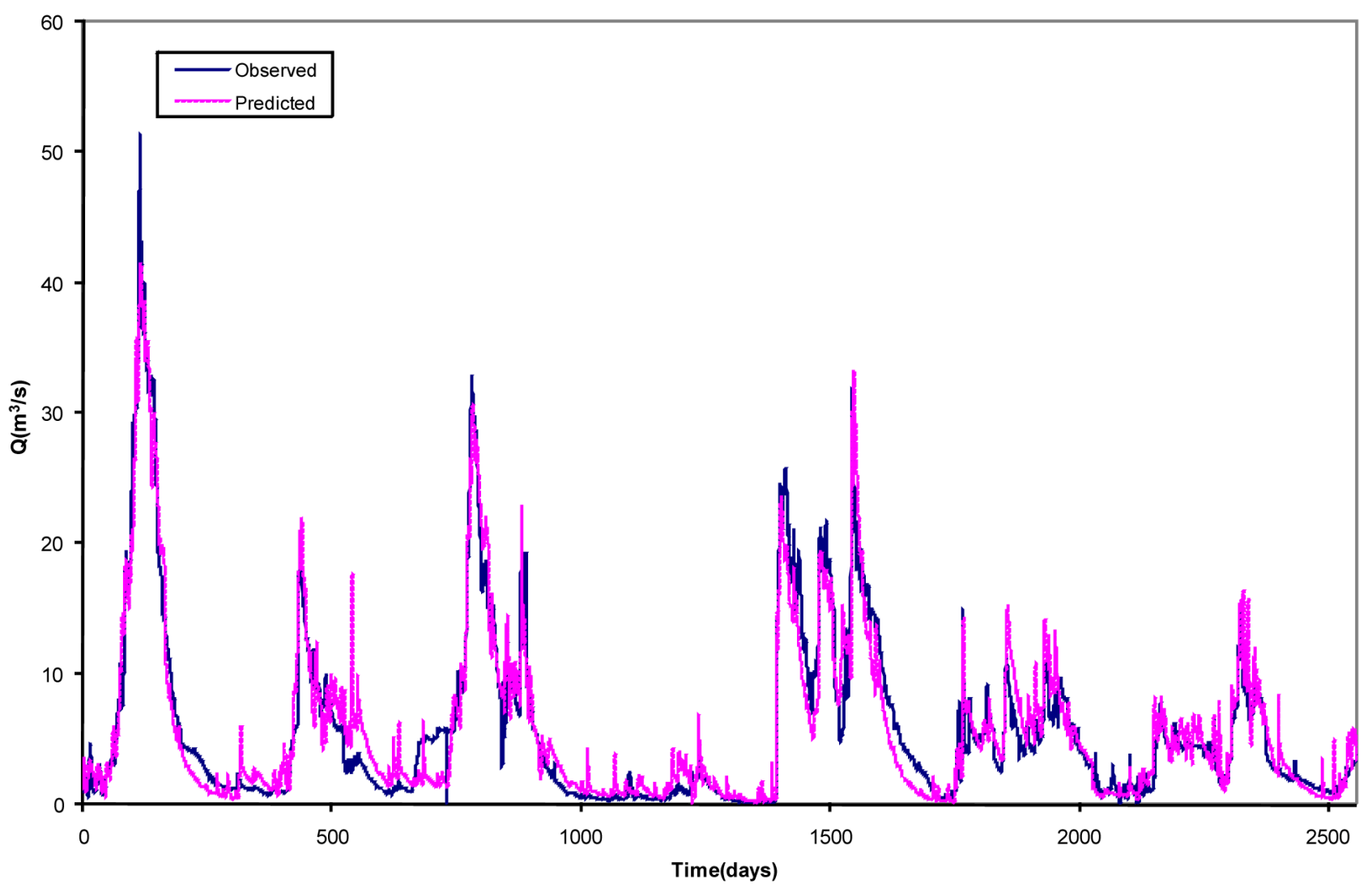

Figure 4. Simulated and observed hydrographs for calibration period during 1996-2002. 


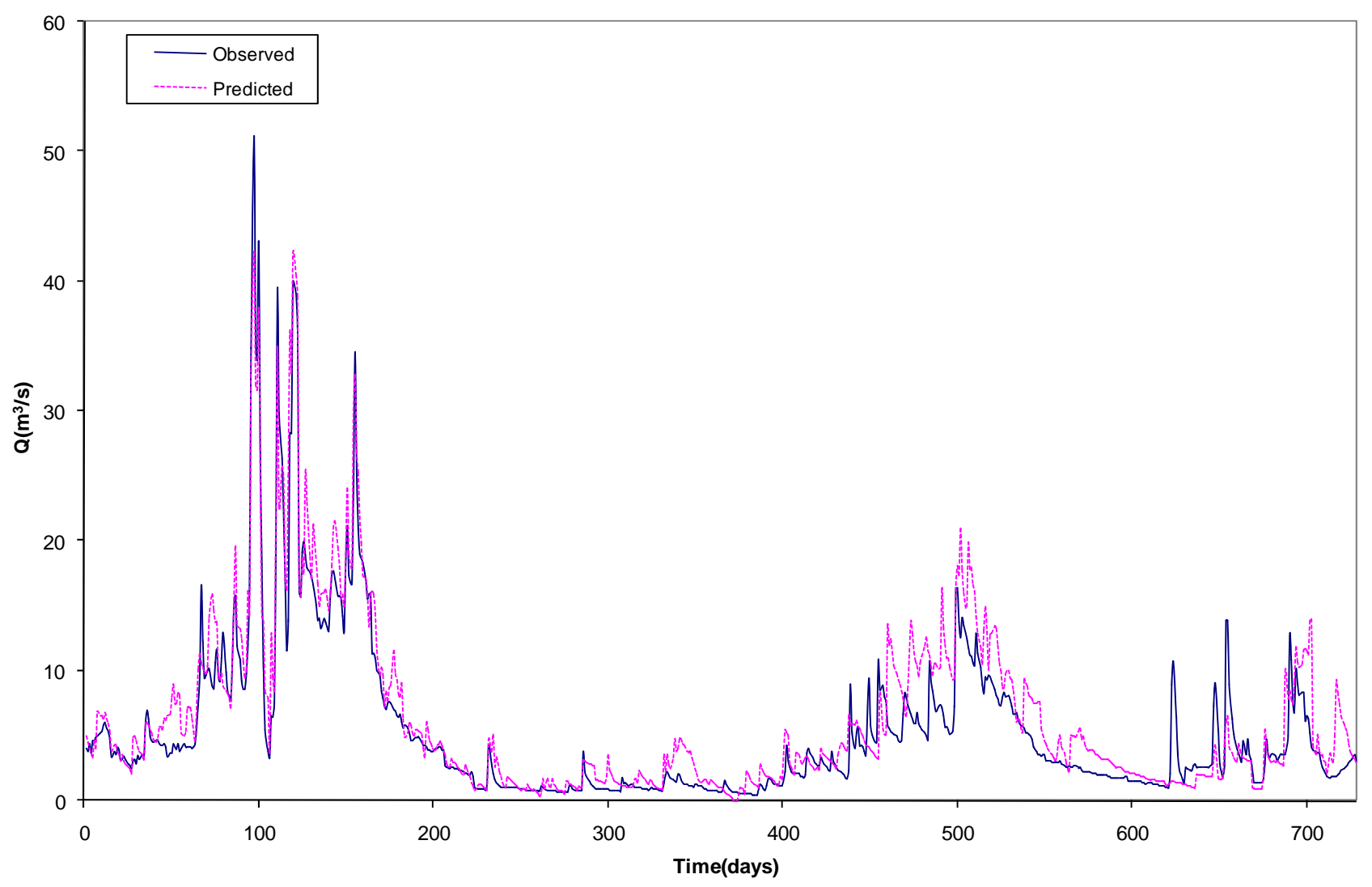

Figure 5. Simulated and observed hydrographs for validation period during 2003-2004.

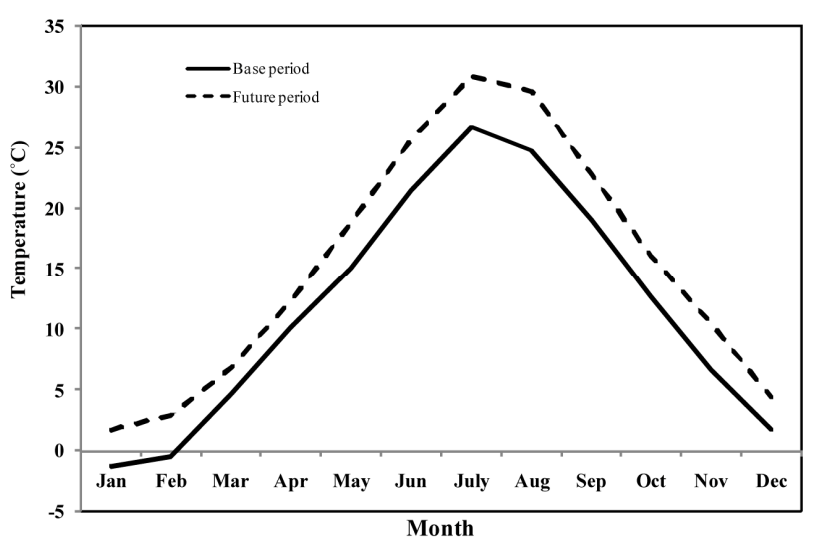

Figure 6. Mean of temperature in Ardabil station for the base (1961-1990) and future (2070-2100) period.

precipitation and temperature patterns. Therefore, precipitation and temperature patterns are prepared for all months using these methods. Future monthly precipitation and temperature patterns are retrieved using the explained method in Section 3.1.3. The samples of precipitation and temperature patterns in January of 2100 are shown in Figures 8 and 9.

\subsection{Future Discharge Results}

After calibration and validation of HSPF model to the

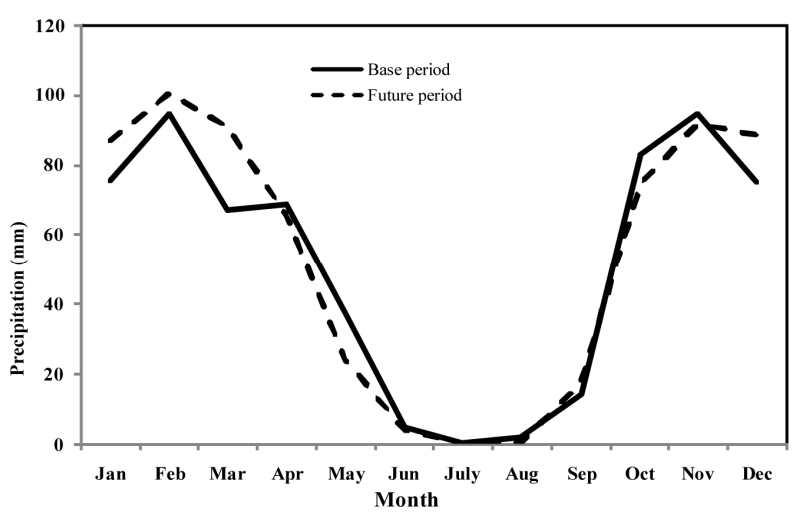

Figure 7. Mean of precipitation in Ardabil station for the base (1961-1990) and future (2070-2100) period.

watershed, PRECIS model base and future data series is used as the input to HSPF model. Table 6 shows the difference between monthly discharges for base (1960-1990) and future (2070-2100) periods. In spite of April, monthly discharges of future period decrease in all of the months. The differences between monthly discharge of base and future periods in the warm months are more than the other months; this is because of increase of future temperature and evapotranspiration and decrease of future precipitation in the warm months in comparison with base data. The least discharge difference is $28 \%$, which 
Table 4. RMSE values of the six interpolation methods for precipitation data.

\begin{tabular}{|c|c|c|c|c|c|c|c|c|c|c|c|c|}
\hline Methods & Jan & Feb & Mar & Apr & May & Jun & July & Aug & Sep & Oct & Nov & Dec \\
\hline IDW & 21.44 & 33.38 & 21.20 & 23.65 & 34.44 & 16.35 & 18.95 & 2.63 & 2.82 & 27.03 & 24.25 & 22.24 \\
\hline Global polynomial & 21.73 & 34.33 & 22.52 & 25.55 & 36.11 & 16.76 & 19.45 & 2.69 & 3.15 & 24.07 & 27.50 & 21.35 \\
\hline $\mathrm{RBF}$ & 20.85 & 31.01 & 20.59 & 19.63 & 32.18 & 16.08 & 18.62 & 2.55 & 2.05 & 23.78 & 24.77 & 21.12 \\
\hline Ordinary Kriging & 22.37 & 33.60 & 21.67 & 23.32 & 33.37 & 17.04 & 18.66 & 2.62 & 2.89 & 21.73 & 23.82 & 21.14 \\
\hline
\end{tabular}

Table 5. RMSE values of the six interpolation methods for temperature data.

\begin{tabular}{|c|c|c|c|c|c|c|c|c|c|c|c|c|}
\hline Method & Jan & Feb & Mar & Apr & May & Jun & July & Aug & Sep & Oct & Nov & Dec \\
\hline IDW & 4.88 & 2.81 & 4.22 & 2.34 & 2.56 & 3.39 & 3.49 & 4.72 & 4.37 & 6.13 & 6.33 & 3.95 \\
\hline Global polynomial & 6.16 & 3.64 & 5.91 & 2.36 & 3.35 & 4.18 & 4.50 & 5.82 & 5.56 & 7.97 & 9.04 & 5.54 \\
\hline $\mathrm{RBF}$ & 5.15 & 2.78 & 4.13 & 2.24 & 2.42 & 3.51 & 3.62 & 4.99 & 4.63 & 5.96 & 6.07 & 4.08 \\
\hline Ordinary Kriging & 4.96 & 2.62 & 3.78 & 2.20 & 2.32 & 3.50 & 3.76 & 4.81 & 4.99 & 6.45 & 6.55 & 4.23 \\
\hline
\end{tabular}

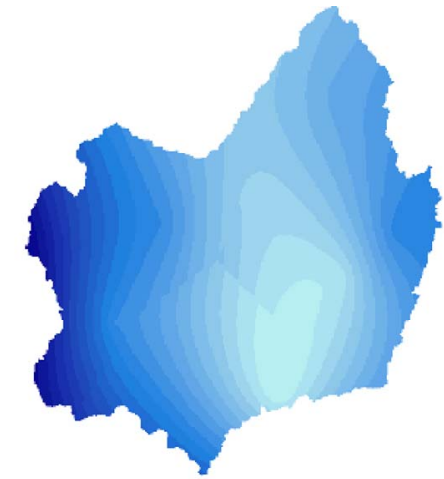

PRECIPITATION (mm)

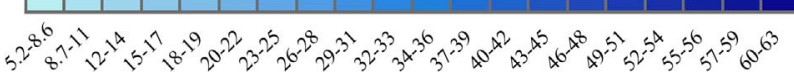

Figure 8. Precipitation pattern on January of 2100.

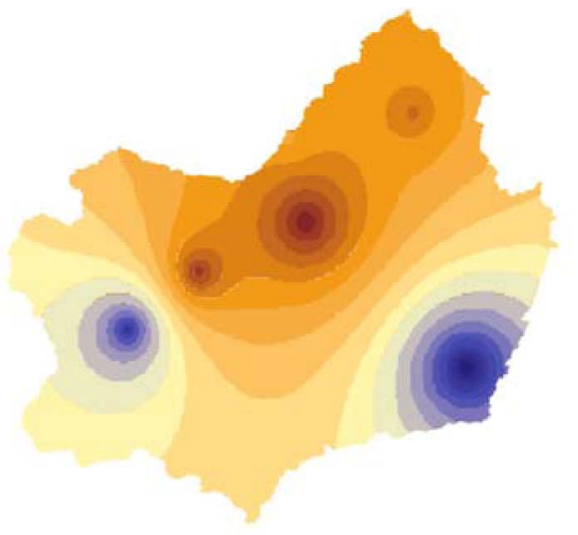

TEMP $\left({ }^{\circ} \mathrm{C}\right)$

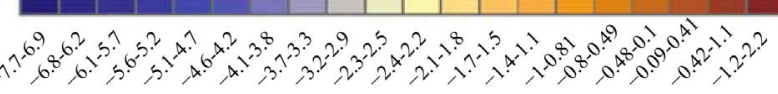

Figure 9. Temperature pattern on January of 2100. takes place on April (Table 6).

Figure 10 shows monthly discharge in the future and base periods. This figure demonstrates that the peak discharge in the future period would happen one month earlier. It is because of increasing temperature and earlier beginning of snow melting. Generally, results show that in the future, the discharge of Gharehsoo River watershed would decrease in the all of months. It might make problem for agriculture of studied region; because, Gharehsoo watershed is one of the most important regions for production of crops in Iran and plays an important role in economic growth and food of this country.

\subsection{Sensitivity Analysis}

In this section, the sensitivity of precipitation and temperature to runoff is investigated. Sensitivity analysis is performed in four hypothetical scenarios for future climate (Table 7). In two hypothetical scenarios, the precipitation is increased and decreased 20 percent. In the other scenarios, the temperature is increased $1{ }^{\circ} \mathrm{C}$ and $2^{\circ} \mathrm{C}$. Results of sensitivity analysis are exhibited in Figure 11. It is obvious that $1{ }^{\circ} \mathrm{C}$ and $2{ }^{\circ} \mathrm{C}$ increase of temperature lead to $0 \%-8 \%$ and $0.1 \%-15 \%$ decrease of average monthly discharge, respectively. In addition, Figure 11 exhibits that monthly discharge increases 0.3 - 35.6 percent due to $20 \%$ increase of precipitation. Similarly, monthly discharge decreases $0.3-32.6$ percent due to $20 \%$ decrease of precipitation.

\section{Conclusions}

HSPF was utilized in this study as a hydrological model. The results of calibration and validation of this model demonstrated its ability for runoff simulation in the 
Table 6. Difference between monthly discharges in the base and future periods.

\begin{tabular}{ccccccccccccc}
\hline Period & Jan & Feb & Mar & Apr & May & Jun & Jul & Aug & Sep & Oct & Nov & Dec \\
\hline Base period & 22.78 & 11.16 & 19.36 & 53.42 & 82.35 & 77.83 & 37.64 & 16.39 & 8.12 & 6.47 & 32.35 & 78.46 \\
Future period & 21.76 & 7.32 & 10.29 & 53.70 & 49.67 & 27.50 & 15.06 & 5.34 & 2.67 & 5.05 & 18.78 & 41.46 \\
Changes & -1.03 & -3.84 & -9.07 & 0.28 & -32.69 & -50.32 & -22.58 & -11.04 & -5.45 & -1.42 & -13.57 & -37.00 \\
Percent of changes & -4.50 & -34.41 & -46.84 & 0.53 & -39.69 & -64.66 & -60.00 & -67.40 & -67.08 & -21.97 & -41.95 & -47.16 \\
\hline
\end{tabular}

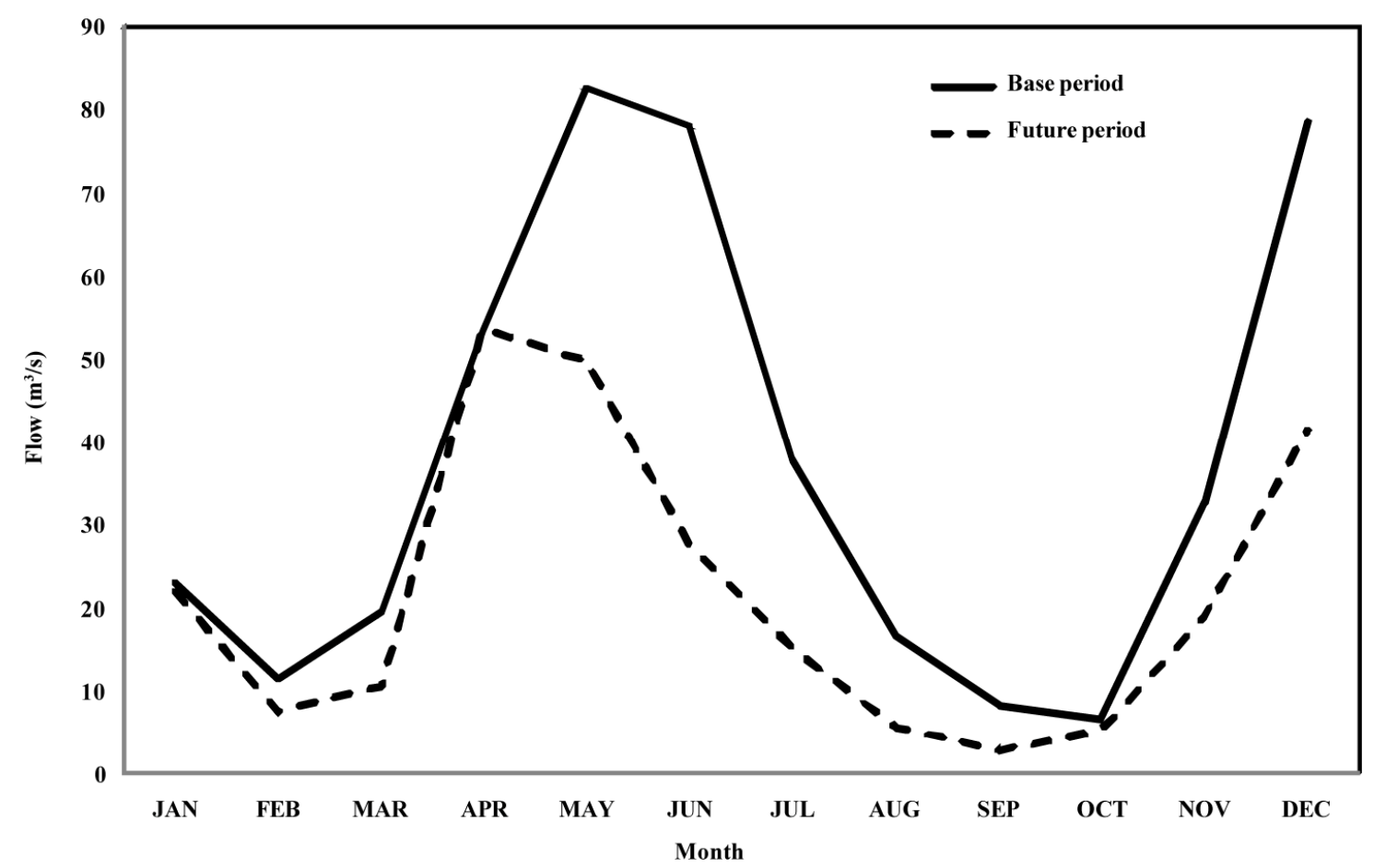

Figure 10. Monthly discharge future and base period.

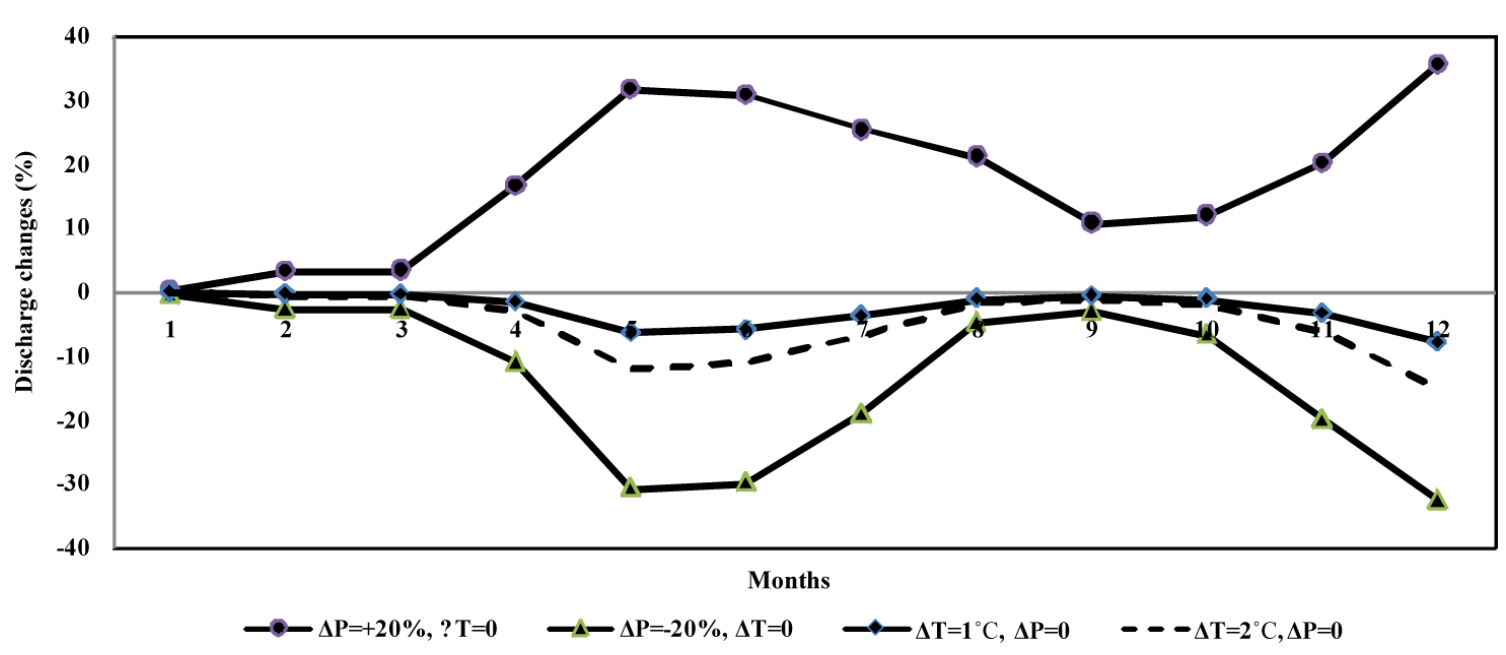

Figure 11. Results of sensitivity analysis of mean monthly runoff to the precipitation and temperature in the Gharehsoo River watershed.

Gharehsoo River. In this study, the different geostatistical methods were utilized for the estimation of present monthly patterns of precipitation and temperature. The cross validation technique was utilized for evaluation of different geostatistical methods. The results showed that the best methods for extraction of precipitation and temperature pattern are RBF and IDW methods, respectively. PRECIS as a regional climate model was utilized to pro- 
Table 7. Hypothetical scenarios of future climate.

\begin{tabular}{ccccc}
\hline & & \multicolumn{3}{c}{ Precipitation scenarios } \\
\cline { 2 - 5 } & & $\Delta \mathrm{P}=-20 \%$ & $\Delta \mathrm{P}=+20 \%$ & $\Delta \mathrm{P}=0$ \\
\hline \multirow{4}{*}{ Temperature scenarios } & $\Delta \mathrm{T}=0$ & $\square$ & $\square$ & - \\
& $\Delta \mathrm{T}=1^{\circ} \mathrm{C}$ & - & - & $\square$ \\
& $\Delta \mathrm{T}=2^{\circ} \mathrm{C}$ & - & - & $\square$ \\
\hline
\end{tabular}

duce climate data of base (1960-1990) and future (20702100 ) periods based on B2 scenario with $50 \times 50 \mathrm{~km}$ resolution. In addition, by combination of base and future precipitation and temperature data with the extracted precent patterns for precipitation and temperature, the future patterns for monthly precipitation and temperature were extracted. The comparison between base and future monthly precipitation and temperature showed that future precipitation is more than the base precipitation on January, February, March, September and December and future temperature increases $2^{\circ} \mathrm{C}-4^{\circ} \mathrm{C}$ in winter, $2^{\circ} \mathrm{C}-5^{\circ} \mathrm{C}$ in spring, $3^{\circ} \mathrm{C}-5^{\circ} \mathrm{C}$ in summer and $2^{\circ} \mathrm{C}-4^{\circ} \mathrm{C}$ in autumn.

The base and future precipitation and temperature patterns were introduced to validated HSPF model for the simulation of monthly runoff in the base and future periods. The results show that in the future, the discharge of Gharehsoo River watershed decreases in all of the months. In addition, the peak discharge in the future period happens one month earlier, because of increase of temperature and earlier beginning of snow melting season. Finally, the sensitivity of precipitation and temperature to runoff was investigated and the results showed that $1{ }^{\circ} \mathrm{C}$ and $2{ }^{\circ} \mathrm{C}$ increase of temperature leads to $0 \%-8 \%$ and $0.1 \%-15 \%$ decrease of average monthly discharge, respectively. In addition, monthly discharge increases $0.3 \%$ $35.6 \%$ and decreases $0.3 \%-32.6 \%$ due to $20 \%$ increase and decrease of precipitation, respectively.

\section{REFERENCES}

[1] L. Nash and P. Gleick, "The Sensitivity of Streamflow in the Colorado Basin to Climatic Changes," Journal of Hydrology, Vol. 125, No. 3, 1991, pp. 221-241. http://dx.doi.org/10.1016/0022-1694(91)90030-L

[2] R. L. Wilby, L. E. Hay and G. H. Leavesley, "A Comparison of Downscaled and Raw GCM Output: Implications for Climate Change Scenarios in the San Juan River Basin, Colorado," Journal of Hydrology, Vol. 225, No. 1, 1999, pp. 67-91. http://dx.doi.org/10.1016/S0022-1694(99)00136-5

[3] W. Arnell, "Climate Change and Global Water Resources," Journal of Global Environmental Change, Vol. 9, No. 1, 1999, pp. 31-49.

[4] P. S. Yu, T. C. Yang and C. K. Wu, "Impact of Climate Change on Water Resources in Southern Taiwan," Journal of Hydrology, Vol. 260, No. 1, 2002, pp. 161-175. http://dx.doi.org/10.1016/S0022-1694(01)00614-X

[5] T. G. Huntington, "Climate Warming Could Reduce Run- off Significantly in New England, USA," Journal of Agricultural and Forest Meteorology, Vol. 117, No. 3-4, 2003, pp. 193-201. http://dx.doi.org/10.1016/S0168-1923(03)00063-7

[6] H. Chen, S. Guo, C. Y. Xu and V. P. Singh, "Historical Temporal Trends of Hydro-Climatic Variables and Runoff Response to Climate Variability and Their Relevance in Water Resource Management in the Hanjiang Basin," Journal of Hydrology, Vol. 344, No. 3-4, 2007, pp. 171184. http://dx.doi.org/10.1016/j.jhydrol.2007.06.034

[7] M. Akhtar, N. Ahmad and M. J. Booij, "The Impact of Climate Change on the Water Resources of HindukushKarakorum-Himalaya Region under Different Glacier Coverage Scenarios," Journal of Hydrology, Vol. 355, No. 1, 2008, pp. $148-163$. http://dx.doi.org/10.1016/j.jhydrol.2008.03.015

[8] S. Vicune, R. D. Garreaud and J. McPhee, "Climate Change Impacts on the Hydrology of a Snowmelt Driven Basin in Semiarid Chile," Journal of Climatic Change, Vol. 105, No. 3, 2011, pp. 469-488.

http://dx.doi.org/10.1007/s10584-010-9888-4

[9] M. Zarghami, A. Abdi, I. Babaeian, Y. Hassanzadeh and R. Kanani, "Impacts of Climate Change on Runoffs in East Azerbaijan, Iran," Journal of Global and Planetary Change, Vol. 78, No. 3-4, 2011, pp. 137-146. http://dx.doi.org/10.1016/j.gloplacha.2011.06.003

[10] V. M. F. Jacomino and E. D. Fields, "A Critical Approach to the Calibration of a Watershed Model," Journal of American Water Resource Association, Vol. 33, No. 1, 1997, pp. 143-154. http://dx.doi.org/10.1111/j.1752-1688.1997.tb04091.x

[11] M. Albek, U. Ogutveren and E. Albek, "Hydrological Modeling of Seydi Suyu Watershed (Turkey) with HSPF," Journal of Hydrology, Vol. 285, No. 1, 2004, pp. 260-271. http://dx.doi.org/10.1016/j.jhydrol.2003.09.002

[12] J. C. Imhoff, J. L. Kittle, M. R. Gray and T. E. Johnson, "Using the Climate Assessment Tool (CAT) in US EPA BASINS Integrated Modeling System to Assess Watershed Vulnerability to Climate Change," Journal of Water Science \& Technology, Vol. 56, No. 8, 2007, pp. 49-56. http://dx.doi.org/10.2166/wst.2007.595

[13] N. Al-Abed and M. Al-Sharif, "Hydrological Modeling of Zarqa River Basin-Jordan Using the Hydrological Simulation Program-FORTRAN (HSPF) Model," Water Resources Management, Vol. 22, No. 9, 2008, pp. 12031220. http://dx.doi.org/10.1007/s11269-007-9221-9

[14] F. Abdulla, T. Eshtawi and H. Assaf, "Assessment of the Impact of Potential Climate Change on the Water Balance of a Semi-Arid Watershed," Water Resources Management, Vol. 23, No. 10, 2009, pp. 2051-2068. http://dx.doi.org/10.1007/s11269-008-9369-y

[15] C. C. Gordon, R. Cooper, C. A. Senior, H. Banks, J. M. Gregory, T. C. Johns, J. F. B. Mitchell and R. A. Wood, "The Simulation of SST, Sea Ice Extents and Ocean Heat Transports in a Version of the Hadley Centre Coupled Model without Flux Adjustments," Climate Dynamics, Vol. 16, No. 2-3, 2000, pp. 147-168. http://dx.doi.org/10.1007/s003820050010

[16] R. G. Jones, M. Noguer, D. C. Hassell, D. Hudson, S. S. 
Wilson, G. J. Jenkins and J. F. B. Mitchell, "Generating High Resolution Climate Change Scenarios Using PRECIS," Met Office Hadley Centre, Exeter, 2004.

[17] K. Johnston, J. M. VerHoef, K. Krivoruchko and N. Lucas, "Using ArcGIS Geostatistical Analyst," ESRI Press, Redlands, 2001.

[18] H. H. Crawford and R. K. Linsley, "Simulation in Hydrology: Stanford Watershed Model IV," Technical Report No. 39, Stanford University, Stanford, 1966.

[19] A. S. Donigian and H. H. Davis, “User's Manual for Agricultural Runoff Management (ARM) Model," USEPA, Athens, 1978.

[20] A. S. Donigian and N. H. Crawford, "Modelling Nonpoint Pollution from the Land Surface," Environmental Research Laboratory, Athens, 1976.

[21] A. S. Donigian and W. C. Huber, "Modeling of Nonpoint Source Water Quality in Urban and Non-Urban Areas," USEPA, Athens, 1991.

[22] A. S. Donigian, B. R. Bicknell and J. C. Imhoff, "Hydrological Simulation Program-FORTRAN (HSPF)," In: V. P. Singh, Ed., Computer Models of Watershed Hydrology, Water Resources Pubs, Highlands Ranch, 1995, pp. 395442.

[23] Hydrocomp Inc., "Hydrocomp Water Quality Operations Manual,” Hydrocomp, Inc., Palo Alto, 1997.
[24] B. R. Bicknell, J. C. Imhoff, J. L. Kittle, T. H. Jobes and A. S. Donigian, "Hydrological Simulation Program Fortran: User's Manual for Release 12.2. US EPA Ecosystem Research Division, Athens, GA and US," 2005.

[25] E. S. Chung, K. Park and K. S. Lee, "The Relative Impacts of Climate Change and Urbanization on the Hydrological Response of a Korean Urban Watershed," Journal of Hydrological Processes, Vol. 25, No. 4, 2011, pp. 544560. http://dx.doi.org/10.1002/hyp.7781

[26] B. R. Bicknell, J. C. Imhoff, J. L. Kittle, R. C. Johanson and A. S. Donigian, "Hydrological Simulation ProgramFortran User's Manual for Release 10," Environmental Research Laboratory Office of Research and Development US Environmental Protection Agency, Athens, 1993.

[27] A. S. Donigian, B. R. Bicknell, J. C. Imhoff and J. L. Kittle, "Application Guide for Hydrological Simulation Program-Fortran (HSPF)," Prepared for US EPA, EPA600/3-84-065, Environmental Research Laboratory, Athens, GA, 1984.

[28] EPA, "BASINS Technical Note 6," Estimating Hydrology and Hydraulic Parameters for HSPF, 2001.

[29] R. K. Linsley, M. A. Kohler and J. L. H. Paulhus, "Hydrology for Engineers," McGraw-Hill, New York, 1988. 